\title{
Differential Regulation of Galectin Expression/Reactivity during Wound Healing in Porcine Skin and in Cultures of Epidermal Cells with Functional Impact on Migration
}

\author{
J. KLÍMA ${ }^{1,2}$, L. LACINA ${ }^{2,3,4}$, B. DVOŘÁNKOVÁ ${ }^{2,3}$, D. HERRMANN ${ }^{5}$, \\ J. W. CARNWATH ${ }^{5}$, H. NIEMANN ${ }^{5}$, H. KALTNER ${ }^{6}$, S. ANDRÉ ${ }^{6}$, J. MOTLÍK ${ }^{1,2}$, \\ H.-J. GABIUS ${ }^{6}$, K. SMETANA JR. ${ }^{2,3}$
}

${ }^{1}$ Institute of Animal Physiology and Genetics, Academy of Sciences of the Czech Republic, Liběchov, ${ }^{2}$ Charles University in Prague, Second Faculty of Medicine, Center of Cell Therapy and Tissue Repair, Prague, ${ }^{3}$ Charles University in Prague, First Faculty of Medicine, Institute of Anatomy, Prague, ${ }^{4}$ Charles University in Prague, First Faculty of Medicine, Department of Dermatovenerology, Prague, Czech Republic, ${ }^{5}$ Department of Biotechnology, Institute of Farm Animal Genetics (FAL), Mariensee, Neustadt, ${ }^{6}$ Ludwig-Maximilians-University in Munich, Faculty of Veterinary Medicine, Institute of Physiological Chemistry, Munich, Germany

Received June 11, 2008

Accepted September 29, 2009

On-line December 17, 2008

\section{Summary}

The glycophenotyping of mammalian cells with plant lectins maps aspects of the glycomic profile and disease-associated alterations. A salient step toward delineating their functional dimension is the detection of endogenous lectins. They can translate sugar-encoded changes into cellular responses. Among them, the members of the lectin family of galectins are emerging regulators of cell adhesion, migration and proliferation. Focusing on galectins $-1,-3$ and -7 , we addressed the issue whether their expression is regulated during wound healing in porcine skin as model. A conspicuous upregulation is detected for galectin- 1 in the dermis and a neoexpression in the epidermis, where an increased level of galectin-7 was also found. Applying biotinylated tissue lectins as probes, the signal intensities for accessible binding sites decreased, intimating an interaction of the cell lectin with reactive sites. In contrast, galectin-3 parameters remained rather constant. Of note, epidermal cells in culture also showed an increase in expression/presence of galectin-1, measured on the levels of mRNA and protein, in this case by Western blotting and quantitative immunocytochemistry. Used as matrix, galectin-1 conferred resistance to trypsin treatment to attached human keratinocytes and reduced migration into scratch-wound areas in vitro. This report thus presents new information on endogenous lectins in wound healing and differential regulation among the three tested cases.

\section{Key words}

Epidermis • Keratinocytes $\bullet$ Lectin $\bullet$ Skin $\bullet$ Wound healing

\section{Corresponding author}

K. Smetana Jr., Charles University in Prague, First Faculty of Medicine, Institute of Anatomy, U nemocnice 3, 12800 Prague 2, Czech Republic. E-mail: karel.smetana@If1.cuni.cz

\section{Introduction}

The integrity of the mammalian skin and the functional interplay between its cellular components are vital for the organism. On the cellular level, the dermis, for example, assists the epithelial layer by supplying oxygen and nutrients from dermal capillaries. The majority of cells constituting the epidermis are keratinocytes. Central to self-renewal the pool of proliferating cells resides in the basal layer of the epithelium. Epidermal stem cells can also be found in the basal layer and in the bulge of the outer root sheath of the hair follicle (Cotsarelie et al. 1999). Any damage to the skin's integrity will rapidly induce a series of events, which account for remodeling of dermal connective 
tissue, migration of epidermal cells and enhancement of their proliferation in an orchestrated manner, to facilitate swift wound closure (Brakebusch 2005).

Our initial focus in this respect has been the study whether these processes are accompanied by changes in glycosylation. Based on the concept of the sugar code glycan determinants of glycoproteins and glycolipids are viewed as biochemical signals, which will be decoded by sugar receptors in the tissue (Gabius 2006, 2009, Gabius et al. 2004). Phenomenologically, we have previously reported on differentiation-dependent changes in distinct aspects of glycosylation in squamous epithelia, especially the status of sialylation, by applying plant lectins and the introduction of a distinct class of endogenous lectins to respective cyto- and histochemical monitoring including the aspect of senescence (Holíková et al. 2002, Chovanec et al. 2004, Plzák et al. 2005). Homing in on spatially accessible termini of glycan branches on glycoproteins such as fibronectin or laminin, the members of the galectin family are capable to trigger a series of responses in cells, e.g. cell attachment or migration and apoptosis/proliferation, after their binding to specific targets (Villalobo et al. 2006). Moreover, the pentasaccharide of ganglioside $\mathrm{GM}_{1}$ is a target, and binding of the homodimeric proto-type galectins- 1 and -7 induces inhibition of proliferation in neuroblastoma cells, the chimera-type galectin-3 acting as antagonist (Kopitz et al. 1998, 2001, 2003). The structural analysis of galectin-1 and the way it interacts with the $\mathrm{GM}_{1}$ glycan reveals an extended binding site with capacity even for selecting a distinct sugar conformation (Siebert et al. 2003, López-Lucendo et al. 2004, André et al. 2005a) Notably, galectin binding is also responsive to slight changes in the glycans' structures and surface density, opening versatile ways for affinity regulation (Unverzagt et al. 2002, Wu et al. 2004, 2006, André et al. 2005b, 2007a). That these lectins, especially galectins- 1 and -3 , are also endowed with the capacity to be engaged in specific protein-protein and protein-lipid interactions (Rotblat et al. 2004, Smetana et al. 2006) adds to the interest to monitor profiles of their expression and of accessible binding partners. Respective investigations have so far been mainly performed for squamous cell carcinomas, revealing a correlation to differentiation and prognosis (Delorge et al. 2000, Plzák et al. 2000, 2001, 2004). It is an unresolved issue to describe lectin expression during wound healing in normal skin and to identify any alterations during this process.

This gap in our knowledge, the documented presence of galectins-1, -3 and -7 in normal skin (Smetana et al. 2006) and the evidence that galectins-3 and -7 can play a role in re-epithelialization of corneal wounds (Cao et al. 2002a,b, 2003) explain why we performed a comparative analysis, using porcine skin as a suitable model (Motlík et al. 2007). The aim was to define galectin-dependent parameters (here for the adhesion/growth-regulatory galectins- $1,-3$ and -7 ) during the course of wound healing. The histochemical work with antibodies rigorously controlled for absence of intrafamily cross-reactivity and with labeled lectins as probes is flanked by in vitro experiments using pig and human cells. They reveal parallels between wound healing and cell culture for galectin-1 regulation and insights into activities of galectin-1 when used for coating the plastic substratum.

\section{Material and Methods}

\section{Animals}

Five miniature pigs four to six months of age (15$20 \mathrm{~kg}$ of body weight) were included into the study. Experimental wound lesion was routinely inflicted under anesthesia and aseptic conditions in the surgical facility of the Institute of Animal Physiology and Genetics of the Czech Academy of Science after complete approval of the proposal by the Local Committee for Laboratory Animals. Premedication consisted of i.m. injections of atropin ( 0.5 $\mathrm{mg} / \mathrm{kg}$; Hoechst-Biotika, Martin, Slovakia) and azaperonum $(2 \mathrm{mg} / \mathrm{kg}$; Stresnil, Janssen Pharmaceutica, Beerse, Belgium). For anesthesia, ketamin ( $33 \mathrm{mg} / \mathrm{kg}$ i.m; Narkamon, Spofa, Prague, Czech Republic) and diazepam (2 $\mathrm{mg} / \mathrm{kg}$; Biotika, Slovenská Lupča, Slovakia), then isofluran (1.5-2.0 vol \%; Torrex Pharma, Prague, Czech Republic) together with a mixture of $\mathrm{O}_{2}$ and $\mathrm{N}_{2} \mathrm{O}$ and fentanyl $(0.05 \mathrm{mg} / \mathrm{kg}$ i.v; Janssen Pharmaceutica, Beerse, Belgium) were applied. Using a scalpel blade, the epidermal and partially the dermal parts of the skin were carefully removed up to depth of $1 \mathrm{~mm}$ in a region of $2 \times 15$ $\mathrm{mm}$. The wound was immediately treated with betadine unguent (EGIS Pharmaceuticals, Budapest, Hungary) and covered by sterile dressing. Tissue samples within the healing process were collected 24 and $48 \mathrm{~h}$ thereafter, respectively, and deeply frozen in liquid nitrogen using the Tissue-Tek cryoprotective agent (Christine Gröpl, Tulln, Austria). Thin frozen sections ( $7 \mu \mathrm{m})$ were prepared using Cryocut-E (Reichert-Jung, Wien, Austria). These sections were used for immuno- and galectin cytochemical detection of the studied markers. 
Preparation of porcine and human cells for culture experiments

Three biopsy samples of epidermis covering its entire depth were obtained from lesion-free porcine skin. Three samples of human breast skin were obtained from the Department of Aesthetic Surgery, Third Faculty of Medicine, Charles University in Prague with the informed consent of the patients and full approval of the Local Ethical Committee according to the Helsinki Declaration. Cultures of keratinocytes and dermal fibroblasts were prepared from these samples, as described in detail previously (Purkrábková et al. 2003). Porcine skin with all cell layers was obtained from a local slaughterhouse. Keratinocytes were isolated from thin skin sections containing mostly epidermal and also dermal tissue. The epidermal-epithelial layer was prepared by incubation of small $2 \times 5 \mathrm{~mm}$ sections in a solution containing $10 \mathrm{mg} / \mathrm{ml}$ dispase (P6141; SigmaAldrich, Prague, Czech Republic) solution for $90 \mathrm{~min}$ at $37^{\circ} \mathrm{C}$. After peeling and washing of the epidermal tissue part in phosphate-buffered saline (PBS; pH 7.3) it was subsequently exposed by trypsin solution for digestion (0.5\% trypsin, $0.2 \%$ EDTA; chemicals supplied by Sigma-Aldrich, Prague, Czech Republic) at $37{ }^{\circ} \mathrm{C}$ for 15 min, trypsin activity on the cells was then quenched by addition of fetal calf serum, and single-cell suspensions were prepared. They were washed twice in PBS to remove trypsin and gently resuspended in culture medium.

In further preparations, the samples of human skin were enzymatically treated, enabling to separate epidermis and dermis. The fibroblasts migrating from the small pieces of dermis were cultured in DMEM (SigmaAldrich, Prague, Czech Republic) at $37{ }^{\circ} \mathrm{C}$ and $5 \%$ of $\mathrm{CO}_{2}$. Keratinocytes from the suspended epidermis were propagated following a modified version of the original protocol by Rheinwald and Green (Matoušková et al. 1989).

\section{Cell culture of porcine keratinocytes}

Isolated cells were seeded in $60-\mathrm{mm}$ dishes at a density of 70,000 cells $/ \mathrm{cm}^{2}$. The culture medium consisted of OptiMEM I reduced serum medium containing GlutaMAX (Invitrogen, Karlsruhe, Germany), $5 \%$ fetal bovine serum (Sigma-Aldrich, Prague, Czech Republic), gentamycin (50 $\mu \mathrm{g} / \mathrm{ml}$; Sigma-Aldrich, Prague, Czech Republic), hydrocortisone $0.4 \mu \mathrm{g} / \mathrm{ml}$; Sigma-Aldrich, Prague, Czech Republic), porcine pancreas insulin $(5 \mu \mathrm{g} / \mathrm{ml}$; Sigma-Aldrich, Prague, Czech
Republic), cholera toxin (1 ng/ml; Sigma-Aldrich, Prague, Czech Republic), and epidermal growth factor (10 ng/ml; Sigma-Aldrich, Prague, Czech Republic). One day after seeding non-adherent cells were discarded by a change of the medium and then further changes were carried out every two days. Cells were kept in culture for up to seven days when they reached confluency. To facilitate monitoring by immunocyto-chemistry sterile coverslips were inserted in the $60-\mathrm{mm}$ dishes, and cells were seeded exactly as described above to mimic the processes during the re-epithelialization, i.e. cell migration and proliferation to the stage of confluence and formation of a multilayered epithelial sheath.

\section{Galectin preparation, labeling and antibodies}

Galectins were isolated after recombinant production by affinity chromatography as crucial step, their purity and activity were assessed by one- and twodimensional gel electrophoresis, mass spectrometry and gel filtration as well as by hemagglutination and solidphase and cell-binding assays, also applied after biotinylation under activity-preserving conditions (André et al. 1999, 2004, 2006, 2008, Kopitz et al. 2003, Purkrábková et al. 2003). Polyclonal antibodies from rabbits raised by using the pure galectins as antigens were rigorously controlled for cross-reactivity within the galectin family by ELISA and Western blotting, and any contaminating activity was removed from the immunoglobulin $\mathrm{G}$ fractions by affinity chromatography on resin exposing the reactive lectin (Lohr et al. 2007, 2008).

Attachment, migration and proliferation of human dermal fibroblasts and keratinocytes on galectin-coated substratum

The plastic surface of culture flasks was coated with galectins at a concentration of $20 \mu \mathrm{g} / \mathrm{ml}$ in PBS at room temperature for five hours. The galectin-containing solution was then removed, and the flasks were thoroughly washed. Human keratinocytes from the first and second subcultures were brought into the flasks at a density of 50,000 cells $/ \mathrm{cm}^{2}$. The cells were kept in culture for six days, then the formation of keratinocyte colonies was measured and the strength of their attachment was tested by applying a mixture of solutions of trypsin $(0.25 \% \mathrm{w} / \mathrm{v})$ and EDTA (0.02\% w/v; Sigma-Aldrich, Prague, Czech Republic) at a ratio of 1:1. Fibroblast attachment was also tested on a surface presenting galectin-1 after coating at a concentration of $100 \mu \mathrm{g} / \mathrm{ml}$ 
relative to a control without coating. The dermal fibroblasts were seeded at a density of 10,000 cells $/ \mathrm{cm}^{2}$. Using dermal fibroblasts at this density and keratinocytes at a density of 80,000 cells $/ \mathrm{cm}^{2}$ and a 48 -h culture period cell layers were prepared for a standard wounding experiment, in which recolonization of the wounded area was assessed after $48 \mathrm{~h}$. In addition to galectin-1 coating was also performed with collagen I (Invitrogen, Karlsruhe, Germany) at a concentration of $3.0 \mathrm{mg} / \mathrm{ml}$ in a $6 \%(\mathrm{w} / \mathrm{v})$ solution of $\mathrm{NaCl}$ as positive control.

\section{Immunocytochemistry and immunohistochemistry of} galectin

The frozen sections were rehydrated in PBS, briefly fixed with paraformaldehyde and after thorough washing with PBS processed with the non-cross-reactive polyclonal immunoglobulin $\mathrm{G}$ fractions against galectin$1,-3$ and -7 used at a concentration $10 \mu \mathrm{g} / \mathrm{ml}$ in PBS, including specificity controls to ascertain antigen-specific and second-step reagent-independent staining (Langbein et al. 2007, Lohr et al. 2007, Dvořánková et al. 2008). Running controls with antibody fractions against triiodothyronine, not present in skin, precluded falsepositive results by antibody binding to $\mathrm{F}_{\mathrm{c}}$ receptors. Proliferating cells were visualized in parallel by applying the mouse monoclonal antibody anti-Ki67 (DAKO, Brno, Czech Republic). The biotinylated galectin-1,-3 and -7 used at a concentration of $20 \mu \mathrm{g} / \mathrm{ml}$ in PBS were applied for visualization of accessible binding sites (BS) in sections and cell specimen (Gabius et al. 1991, Plzák et al. 2000, 2001). As second-step reagents FITC (fluoresceinisothiocyanate)-labeled swine anti-rabbit serum (AlSeVa, Praha, Czech Republic), TRITC (tetramethylrhodamineisothiocyanate)-labeled goat anti-mouse serum (Sigma-Aldrich, Prague, Czech Republic) and ExtrAvidin-TRITC (Sigma-Aldrich, Prague, Czech Republic) were used. The nuclei of studied cells were routinely counterstained with DAPI (4',6'-diamidino-2-phenylindole dilactate; SigmaAldrich, Prague, Czech Republic). Finally, all specimens were mounted on Vectashield (Vector Laboratories, Burlingame, CA, USA) and visually inspected by means of a Nikon Eclipse 90i fluorescence microscope (Nikon, Prague, Czech Republic) equipped by suitable filterblocks, a cooled CCD camera Cool-1300Q (Vosskühler, Osnabrück, Germany) and a LUCIA 5.1 computer-assisted image analysis system (Laboratory Imaging, Prague, Czech Republic). Fluorescence intensity was measured under standardized conditions
(Dubový et al. 2002) in 300 cells (or independent sites of the dermis) in each section or coverslip using the software given above.

\section{Western blot analysis}

Primary cell suspensions from intact skin biopsies and cells from the $44^{\text {th }}$ passage of cultured porcine keratinocytes were used as source for extracts. Keratinocytes were solubilized in common SDS lysis buffer, proteins were separated on a $10 \%$ SDS-PAGE gel, then transferred to a PVDF membrane (Millipore, Schwalbach, Germany), and blocking, antibody incubation at a concentration of $1 \mu \mathrm{g} / \mathrm{ml}$ and detection of immunopositive bands by a horseradish peroxidaselabeled goat anti-rabbit antibody and the ECL Plus Western blotting system (GE Healthcare, Freiburg, Germany) were carried out (Kaltner et al. 2002). The signal was visualized on Kodak BioMax Light 1 films exposed to the blots.

\section{$R N A$ isolation and reverse transcription}

Cultured cells were collected by trypsinization for $5 \mathrm{~min}$ at $37^{\circ} \mathrm{C}$, thoroughly washed in PBS, pelleted and frozen at $-74{ }^{\circ} \mathrm{C}$. Frozen cell pellets were lysed and homogenized in $350 \mu \mathrm{l}$ RTL buffer, and total RNA was isolated using the Qiagen RNAeasy mini kit (Qiagen $\mathrm{GmbH}$, Hilden, Germany) according to manufacturer's instructions. Total RNA was eluted in $30 \mu \mathrm{l} \mathrm{H}_{2} \mathrm{O}$, aliquots of $1 \mu \mathrm{g}$ RNA were prepared and stored at $-74{ }^{\circ} \mathrm{C}$. Reverse transcription was performed in a total reaction volume of $20 \mu \mathrm{l}$ containing $1 \mu \mathrm{g}$ total RNA, 1x PCR buffer II, $5 \mathrm{mM} \mathrm{MgCl} 2,2.5 \mu \mathrm{M}$ random hexamers, $1 \mathrm{mM}$ dNTP, $1 \mathrm{U} / \mu \mathrm{l}$ RNase inhibitor and $2.5 \mathrm{U} / \mu \mathrm{l}$ Moloney Murine Leukemia Virus reverse transcriptase (MuLV; all components supplied by Applied Biosystems, Heidelberg, Germany) and the following conditions per cycle: $65{ }^{\circ} \mathrm{C}$ denaturation for $5 \mathrm{~min}, 25{ }^{\circ} \mathrm{C}$ for $10 \mathrm{~min}$ with addition of the $\mathrm{MuLV}$ reverse transcriptase followed by an extension step at $42{ }^{\circ} \mathrm{C}$ for one hour and a final step at $75{ }^{\circ} \mathrm{C}$ for $10 \mathrm{~min}$. The resulting cDNA solution was diluted twice with RNase-free water, and $5 \mu$ aliquots were stored at $-30{ }^{\circ} \mathrm{C}$.

\section{Quantitative PCR}

The cDNA target sequences were amplified and detected using the LightCycler FastStart DNA Master ${ }^{\text {PLuS }}$ SYBR Green I kit (Roche Diagnostics, Mannheim, Germany). In detail, $0.4 \mu \mathrm{l}$ of a solution containing cDNA ( $2 \mathrm{x}$ diluted) template was added to the PCR mix consisting 
of 1x Mastermix and $0.5 \mu \mathrm{M}$ primers in a total volume of $20 \mu \mathrm{l}$. The general qPCR protocol was as follows: preincubation at $95{ }^{\circ} \mathrm{C}$ for $10 \mathrm{~min}$, denaturation at $95{ }^{\circ} \mathrm{C}$ for $10 \mathrm{~s}$, annealing and extension conditions were dependent on the nature of primer and amplicon as indicated below. After each extension step a fluorescence acquisition was done after a two-seconds incubation at $72^{\circ} \mathrm{C}$. After amplification a melting curve was measured using a denaturation at $95{ }^{\circ} \mathrm{C}$ for $10 \mathrm{~s}$, annealing at $65^{\circ} \mathrm{C}$ for $15 \mathrm{~s}$ and melting at a temperature transition rate of $0.1^{\circ} \mathrm{C} / \mathrm{s}$ up to $95{ }^{\circ} \mathrm{C}$ with continuous fluorescence acquisition. Primers used for quantitation of galectin-1 expression were the forward sequence 5'-GGCAAAGACAGCAACAACCT'-3 and the reverse sequence 5'-GGCCACACACTTGATCTTGAA'-3, the predicted length of the amplicon was $293 \mathrm{bp}$, the annealing temperature was $64^{\circ} \mathrm{C}$ for $8 \mathrm{~s}$, extension was carried out at $72{ }^{\circ} \mathrm{C}$ for $12 \mathrm{~s}$. Primers used for quantitation of galectin-3 expression were the forward sequence 5'-TGCCTCGCATGCTGATAACA'-3 and the reverse sequence 5' GGTTCAACCAGGACTTGTAT' ${ }^{\prime}-3$, the predicted length of the amplicon was $238 \mathrm{bp}$, the annealing temperature was $62{ }^{\circ} \mathrm{C}$ for $8 \mathrm{~s}$, the extension conditions were $72{ }^{\circ} \mathrm{C}$ for $10 \mathrm{~s}$. Both amplicons were sequenced to prove their identity. Each PCR reaction for a given gene was normalized to the same amount of total RNA used in the reaction and processing equal cDNA aliquots in subsequent cycles of PCR amplification. Total RNA was isolated in the course of three independent culture experiments, and quantitation of DNA amplicons was performed in triplicates. For each gene and run, a standard curve was established to monitor efficient amplification and to determine relative amplification of the PCR product. Samples with the highest amount of target template were used for serial dilutions corresponding to $1 \mu \mathrm{l}, 0.5 \mu \mathrm{l}, 0.2$ $\mu \mathrm{l}, 0.04 \mu \mathrm{l}, 0.008 \mu \mathrm{l}$ and $0.0016 \mu \mathrm{l}$ of $2 \mathrm{x}$ diluted cDNA in the reaction volume. The actual measurements were carried out in a LightCycler 2.0 instrument (Roche Diagnostics, Mannheim, Germany).

\section{Statistics}

Statistical analysis was performed with NCSS 2000 software (NCSS, Kaysville, UT, USA). The experimental data were processed by repeated measures ANOVA and the Tukey-Kramer multiple comparison test to spot significant differences between groups $(\mathrm{p} \leq 0.05)$. Data obtained by measurements of fluorescence intensities in tissue sections and cultured cells were analyzed using the non-paired Student t-test.

\section{Results}

Galectin parameters in lesion-free skin and during wound healing

We first performed immunohistochemical detection of the two most commonly studied family members, i.e. galectin- 1 and -3 , as reference point. The dermis of normal porcine skin showed a weak to medium immunopositivity for galectin-1, whereas the epidermis was negative (Fig. 1A). The healing process after inflicting a lesion was associated with an increase in dermal expression and occurrence in the epidermis (Figs 1B-1C). To reveal whether this regulation was linked to cell proliferation, we monitored presence of the respective marker Ki67. No apparent correlation was noted, with galectin-1 presence visible in both Ki-67positive and -negative cells (Figs 1B-1C). Running these experiments in the case of galectin-3 revealed its presence in lesion-free epidermis and no effect of healing on the signal intensity (Figs 1D-1E). In contrast, the intensities for the galectin-1-dependent signals were significantly enhanced, as shown by presenting the data of the quantitative analysis (Fig. 1F). Having herewith detected differences on the level of galectin expression, we next explored whether a regulation is operative on the level of accessible binding partners for the galectins. Toward this end, we processed these sections with labeled galectins.

The application of galectin-1 led to a positive reaction in the skin, and the intensity of the signal was significantly reduced upon wound healing (Figs 2A, 2B and 2E). Galectin-3-binding sites were visualized predominantly on the surface of epidermal keratinocytes, and the intensity of the signal was not affected by the healing process (Figs 2C-2E). In comparison, the reactivity for labeled galectin-3 was significantly reduced in the dermis in the process of re-epithelialization (Figs 2C-2E). We next added analysis of galectin-7dependent parameters and detected a strong increase in immunopositivity in epidermal cells during wound healing (Figs 2F-2H) associated with a correlating sharp decrease in binding reactivity (Figs $2 \mathrm{I}-2 \mathrm{~K}$ ). These results informed us about an influence of wound healing in vivo on galectin parameters and prompted further cell biological work.

\section{Galectin parameters in cultured porcine keratinocytes}

To set a standard for cell preparations from normal skin, we first asked the question whether cell 

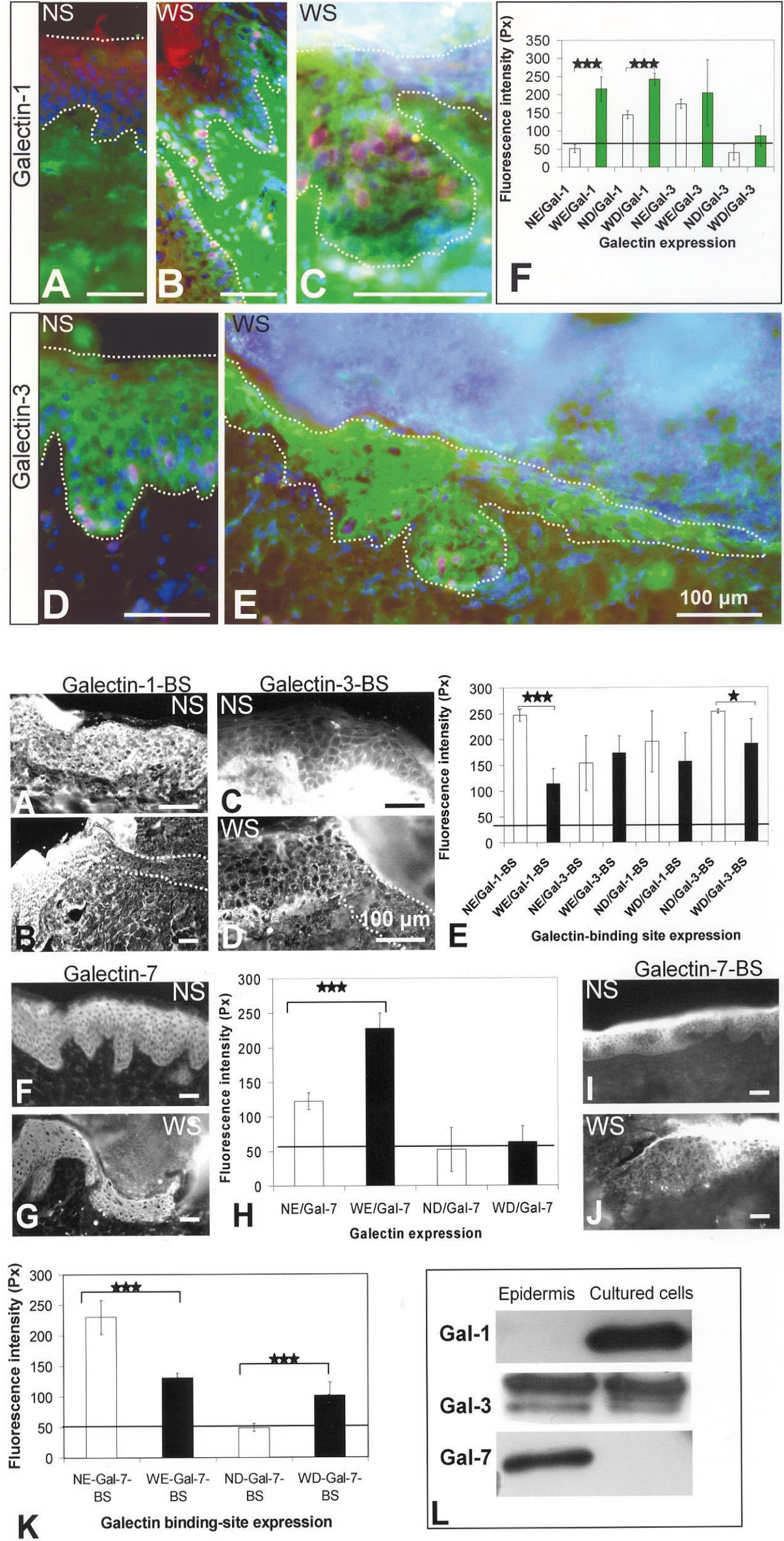

Fig. 1. Immunohistochemical detection of galectin-1 (green signal, AC), galectin-3 (green signal, D,E) and the proliferation marker Ki67 (red signal, A-E) in sections of normal porcine skin (NS; A,D) and skin $48 \mathrm{~h}$ after wounding (WS; $\mathbf{B}, \mathbf{C}, \mathbf{E})$. The epidermal area is delimited by a dashed white line (bar: $100 \mu \mathrm{m}$ ). Panel $\mathrm{F}$ presents quantitative aspects (mean \pm S.D.) of the intensity of the fluorescence signal in normal epidermis (NE), wounded epidermis (WE), normal (ND) and wounded dermis (WD). The horizontal line represents background signal. $* * *$ significant difference at $\mathrm{p}=0.001$.

Fig. 2. Lectin or immunohistochemical detection of accessible binding sites for galectin-1 (A, B,E), binding sites for galectin-3 $(\mathbf{C}, \mathbf{D}, \mathbf{E})$, expression of galectin-7 (F, $\mathbf{G}, \mathbf{H})$, and binding sites for galectin-7 $(\mathbf{I}, \mathbf{J}, \mathbf{K})$ in sections of normal (NS; $\mathbf{A}, \mathbf{C}, \mathbf{F}, \mathbf{I}$ ) and wounded skin (WS; $\mathbf{B}, \mathbf{D}, \mathbf{G}, \mathbf{J})$. Panels $\mathbf{E}, \mathbf{H}, \mathbf{K}$ present quantitative aspects (mean \pm S.D.) of the intensity of the fluorescence signal in normal epidermis (NE), wounded epidermis (WE), normal (ND) and wounded dermis (WD). The horizontal line represents background signal. Three stars stand for a statistically significant difference at $p=0.001$. Panel $L$ shows expression of studied galectins $(-1,-3,-7)$ in epidermis and in cultured keratinocytes detected by Western blot. 
culture may affect galectin expression. To address this issue, we performed Western blot analysis for cells from the epidermis and cultured keratinocytes. As shown in Figure 2L, galectin-3 presence remained rather constant. No evidence for its proteolytic truncation with removal of the collagenase-sensitive $\mathrm{N}$-terminal part besides a minor degradation was observed. In contrast, galectin-1 presence was only seen in the cultured keratinocytes, which lost galectin-7 (Fig. 2L). The result of this biochemical analysis was further supported by cytochemical experiments. They document a gradual increase for galectin-1 tied to decreased reactivity for the labeled lectin, except for strong cytoplasmic staining in mitotic cells, whereas galectin-3 parameters were not notably affected by the period of cell culture. An accumulation at sites of intercellular contact for both lectins and nuclear reactivity with galectin-1 deserved attention. Quantitation of the cytochemical data, together with results of quantitative determination of gene expression, underlines the described courses of parameter changes (Fig. 3).

Cytochemical monitoring of galectin-7 also corroborated the Western blot data, immunoreactivity being confined to areas of multiple cell layers (Fig. 3). No accessible sites for this galectin could be visualized. Evidently, cell culture conditions affected galectin expression and led to an effect on galectin-1 similar to wound healing. The ensuing question was whether the three lectins, especially galectin-1, which can be secreted, may modulate attachment and healing of scratch-wounds in vitro, when presented as a matrix. In these experiments we used human keratinocytes.

Galectins as matrix for attachment and scratch-wound healing in vitro

Attachment of keratinocytes and fibroblasts to the control substratum and to the three surfaces presenting a galectin was rather similar (Figs 4A,B,D,E,J,K). The only observed difference concerned resistance toward trypsin treatment. Here, galectin-1 was especially effective to confer stability (Figs 4C, F, I, L). To collect further information on galectin-1 activities, we tested whether galectin-1 as substratum influences cellular behavior after inflicting a scratchwound. The cell-free area was recolonized by fibroblasts and keratinocytes when cultured on plastic substratum as control or on collagen I (Figs 5A, B, E, F). Presence of galectin-1 negatively affected this process (Figs 5C, D, G, H).
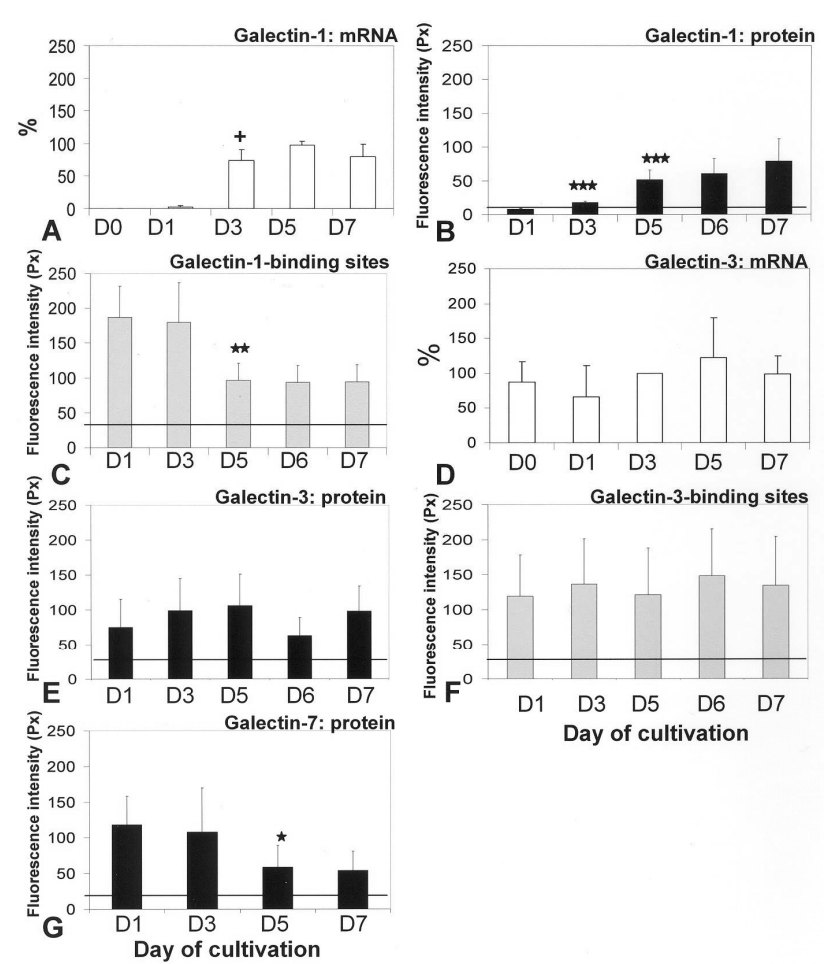

Fig. 3. Comparison of expression of galectin-1 (A,B), galectin-3 $(\mathbf{D}, \mathbf{E})$, galectin-7 (G) and binding sites for galectin-1 (BS; C) and for galectin-3 (F) determined either by RT-PCR analysis (A, D), by quantitative immunocytochemical $(\mathbf{B}, \mathbf{E}, \mathbf{G})$ and lectin cytochemical $(\mathbf{C}, \mathbf{F})$ monitoring in porcine keratinocytes in the course of the seven-day period of culture. Statistically significant differences from the preceding value (RT-PCR, Tukey-Kramer multiple comparison test, cross) and in quantitative immuno/lectin histochemistry at significance levels: $* * * p=0.001$, ** $p=0.02$ and $* p=0.05$ evaluated by the non-paired Student- $t$ test. Results show that galectin-1 expression is significantly upregulated during culture, binding sites for this galectin are significantly reduced. No significant differences in expression of galectin-3 and its binding sites were observed. Expression of galectin-7 (protein) was downregulated after approximately one week in culture.

\section{Discussion}

As a key step toward a functional interpretation of changes in the glycomic profile of cells, the interest in measuring expression of endogenous lectins is evident. In parallel, microarrays for spotting regulatory events in gene expression provide valuable hints for the relevance of distinct proteins with lectin activity in diverse aspects of cell physiology. With respect to corneal re-epithelialization the expression of the galectin-7 gene was among the 37 cases undergoing upregulation from 1176 tested genes with a factor of 5.2, explicitly in mouse cornea after excimer laser injury (Cao et al. 2002b), and the protein promoted the re-epithelialization of corneal wounds (Cao et al. 2002a, 2003). This lectin is expressed at all stages of epidermal differentiation, i.e. in basal and 


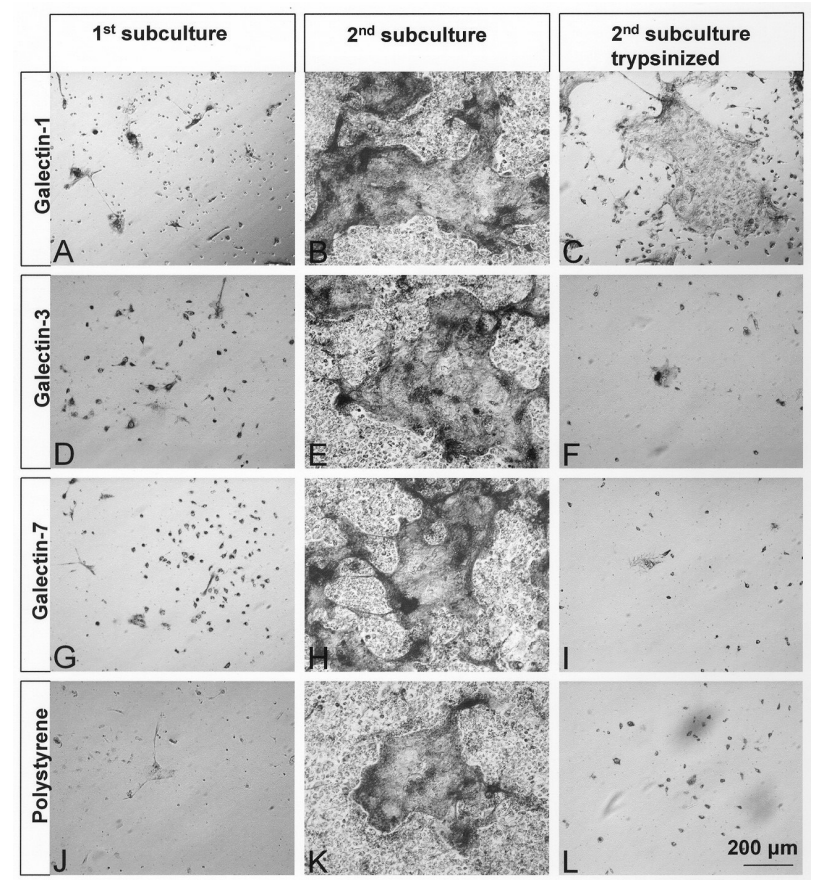

Fig. 4. Comparison of growth features of human keratinocytes in coculture with fibroblasts on a surface precoated with either galectin-1 (A-C), galectin-3 (D-F) or galectin-7 (G-I) as well as on the plastic substratum without a galectin-coating step as control (J-L). A conspicuous resistance to detachment by trypsin treatment was noted for cells on a galectin-1-exposing surface (C). Specimens were stained by hematoxylin-eosin; bar: $200 \mu \mathrm{m}$.

suprabasal layers, and moderately downregulated by treatment of cells with $1 \mu \mathrm{M}$ retinoic acid (Magnaldo et al. 1995). Its sensitivity to SV40 transformation of human K14 keratinocytes and also its upregulation after p53 expression in human DLD-1 colon carcinoma cells ties this galectin's expression to tumor processes (Madsen et al. 1995, Polyak et al. 1997). It shares basic reactivity to $\beta$-galactosides with other galectins. But, as it is turning out, the fine-specificity profiles to oligosaccharides for galectin-1, -3 and -7 can well differ, e.g. for

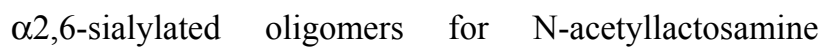
(Ahmad et al. 2002). Regarding gene expression galectin1 is also connected to the activity of a tumor suppressor, i.e. $\mathrm{p} 16^{\mathrm{INK} 4 \mathrm{a}}$, which at the same time affects glycosylation to increase susceptibility to galectin-1's growthregulatory effector mechanisms (André et al. 2007b). These two lectins can thus be regulated by proteins involved in affecting the malignant phenotype. Considering also the evidence from laryngeal and hypopharyngeal squamous cell carcinomas with disparate expression patterns during tumor progression for the two homodimeric galectin-1 and -7 and also the chimera-type galectin-3 (Saussez et al. 2008a,b), it was pertinent to look at these lectins in parallel. Toward this end, we
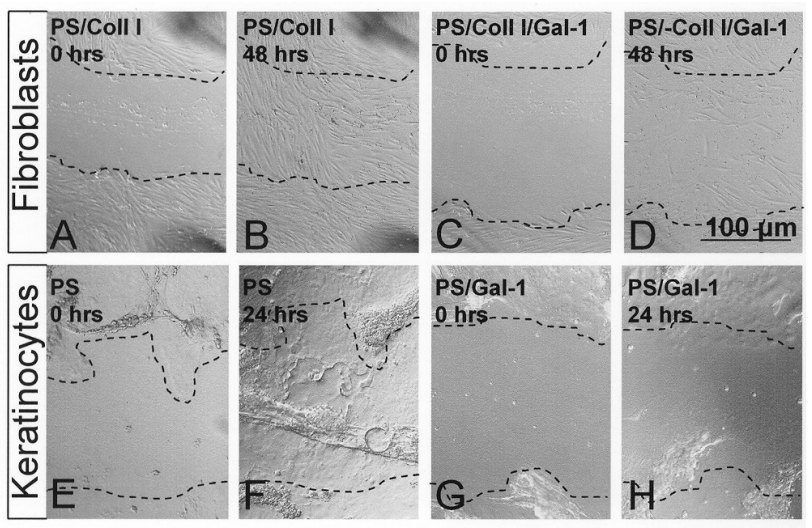

Fig. 5. Recolonization of scratch-wound areas in subconfluent/confluent culture of human dermal fibroblasts (AD) and keratinocytes (E-H) after $48 \mathrm{~h}$. The surface of the culture flasks was coated with collagen I $(\mathbf{A}, \mathbf{B})$, with a mixture of collagen I and galectin-1 $(\mathbf{C}, \mathbf{D})$, and with galectin-1 alone $(\mathbf{G}, \mathbf{H})$, respectively. No coating was performed in the experiments presented in panels $\mathbf{E}, \mathbf{F}$. The site of the initial scratch wound is marked by dashed lines in each case. Bar: $100 \mu \mathrm{m}$.

examined their tissue presence by non-cross-reactive antibodies.

This monitoring resulted in detection of increases in signal intensity in immunohistochemistry. Significantly positive effects were noted for galectin-1 in the dermis and epidermis and also for epidermal presence of galectin-7. Concomitantly, the accessibility of binding sites for both lectins decreased. A general effect on this class of endogenous lectins was excluded by measuring a constant expression level for the chimera-type galectin-3. Evidently, wound repair in pig skin was accompanied by a differential regulation of galectin presence. Modulation was also seen in epidermal cells upon cell culture. These conditions upregulated galectin-1 presence as determined on the level of mRNA as well as protein in western blotting and quantitative immunocytochemistry. Initial functional studies focusing on galectin-1 showed an increased resistance to trypsin-dependent detachment of keratinocytes and fibroblasts from a substratum and reduced closure of scratch-wounds when using a galectin1 -presenting matrix. Of note, this galectin can exert proand anti-adhesive properties in a cell-type-dependent manner (André et al. 1999).

In summary, the reported data indicate that lectin expression is differentially regulated in vivo in the course of wound healing in skin as well as in vitro in culture for epidermal cells. These results give a clear direction for further research, i.e. to define the functional significance of increased galectin-1 expression and to extend galectin monitoring to the tandem-repeat-type subfamily, especially galectin-9 (Lensch et al. 2006). 


\section{Conflict of Interest}

There is no conflict of interest.

\section{Acknowledgements}

This study was supported by the grants MSM0021620806 and 1M0538 from the Ministry of Education, Youth, and Sport of the Czech Republic, an EC grant (MRTN-CT-
2005-019561) for a Marie Curie Research Training Network, the research initiative LMUexcellent and the German-Czech Collaboration in the Field of Agricultural Research (project no. 3/04). The authors are grateful to Eva Vancová, Iva Burdová and Vít Hajdúch for their excellent technical assistance.

\section{References}

AHMAD N, GABIUS H-J, KALTNER H, ANDRÉ S, KUWABARA I, LIU F-T, OSCARSON S, NORBERG T, BREWER CF: Thermodynamic binding studies of cell surface carbohydrate epitopes to galectins- $1,-3$, and -7 : evidence for differential binding specificities. Can J Chem 80: 1096-1104, 2002.

ANDRÉ S, KOJIMA S, YAMAZAKI N, FINK C, KALTNER H, KAYSER K, GABIUS H-J: Galectins-1 and -3 and their ligands in tumor biology. $J$ Cancer Res Clin Oncol 125: 461-474, 1999.

ANDRÉ S, KALTNER H, FURUIKE T, NISHIMURA S-I, GABIUS H-J: Persubstituted cyclodextrin-based glycoclusters as inhibitors of protein-carbohydrate recognition using cells as targets. Bioconjugate Chem 15: 87-98, 2004.

ANDRÈ S, KALTNER H, LENSCH M, RUSSWURM R, SIEBERT HC, FALLSEHR C, TAJKHORSHID E, HECK AJR, VON KNEBEL DOEBERITZ M, GABIUS H-J, KOPITZ J: Determination of structural and functional overlap/divergence of five proto-type galectins by analysis of the growth-regulatory interaction with ganglioside $\mathrm{GM}_{1}$ in silico and in vitro on human neuroblastoma cells. Int J Cancer 114: 46-57, $2005 \mathrm{a}$.

ANDRÉ S, KOJIMA S, PRAHL I, LENSCH M, UNVERZAGT C, GABIUS H-J: Introduction of extended LEC14type branching into core-fucosylated biantennary N-glycan. Glycoengineering for enhanced cell binding and serum clearance of the neoglycoprotein. FEBS J 272: 1986-1998, 2005 b.

ANDRÉ S, PEI Z, SIEBERT H-C, RAMSTRÖM O, GABIUS H-J: Glycosyldisulfides from dynamic combinatorial libraries as O-glycoside mimetics for plant and endogenous lectins: their reactivities in solid-phase and cell assays and conformational analysis by molecular dynamics simulations. Bioorg Med Chem 14: 6314-6326, 2006.

ANDRÉ S, KOZÁR T, SCHUBERTH R, UNVERZAGT C, KOJIMA S, GABIUS H-J: Substitutions in the N-glycan core as regulators of biorecognition: the case of core-fucose and bisecting GlcNAc moieties. Biochemistry 46: 6984-6995, 2007a.

ANDRÉ S, SANCHEZ-RUDERISCH H, NAKAGAWA H, BUCHHOLZ M, KOPITZ J, FORBERICH P, KEMMER W, BÖCK C, DEGUCHI K, DETJEN KM, WIEDENMANN B, VON KNEBEL DOEBERITZ M, GRESS TM, NISHIMURA S-I, ROSEWICZ S, GABIUS H-J: Tumor suppressor p1 $6^{\mathrm{INK} 4 \mathrm{a}}-$ modulator of glycomic profile and galectin-1 expression to increase susceptibility to carbohydrate-dependent induction of anoikis in pancreatic carcinoma cells. FEBS J 274: 3233-3256, 2007 b.

ANDRÈ S, SANSONE F, KALTNER H, CASNATI A, KOPITZ J, GABIUS H-J, UNGARO R: Calix[n]arene-based glycoclusters: bioactivity of thiourea-linked galactose/lactose moieties as inhibitors of binding of medically relevant lectins to a glycoprotein and cell-surface glycoconjugates and selectivity among human adhesion/growth-regulatory galectins. ChemBioChem 9: 1649-1661, 2008.

BRAKEBUSCH J: Keratinocyte migration in wound healing. In Cell Migration in Development and Disease. D WEDLICH (ed), Wiley-VCH, Weinheim, 2005, pp 275-298.

CAO Z, SAID N, AMIN S, WU HK, BRUCE A, GARATE M, HSU DK, KUWABARA I, LIU F-T, PANJWANI N: Galectins-3 and -7, but not galectin-1, play a role in re-epithelialization of wounds. $J$ Biol Chem 277: 4229942305, 2002a.

CAO Z, WU HK, BRUCE H, WOLLENBERG K, PANJWANI N: Detection of differentially expressed genes in healing mouse corneas, using cDNA microarrays. Invest Ophthalmol Visual Sci 43: 2897-2904, $2002 \mathrm{~b}$. 
CAO Z, SAID N, WU HK, KUWABARA I, LIU F-T, PANJWANI N: Galectin-7 as potential mediator of corneal epithelial cell migration. Arch Ophthalmol 121: 82-86, 2003.

CHOVANEC M, SMETANA K JR, DVOŘÁNKOVÁ B, PLZÁKOVÁ Z, ANDRÉ S, GABIUS H-J: Decrease of nuclear reactivity to growth-regulatory galectin-1 in senescent human keratinocytes and detection of nonuniform staining profile alterations upon prolonged culture for galectins-1 and -3. Anat Histol Embryol 33: 348-354, 2004.

COTSARELIS G, KAUR P, DHOUHAILLY D, HENGGE U, BICKENBACH J: Epithelial stem cells in the skin: definition, markers, localization and function. Exp Dermatol 8: 80-88, 1999.

DELORGE S, SAUSSEZ S, PELC P, DEVROEDE B, MARCHANT H, BURCHERT M, ZENG F-Y, DANGUY A, SALMON I, GABIUS H-J, KISS R, HASSID S: Correlation of galectin-3/galectin-3-binding sites with low differentiation status in head and neck squamous cell carcinomas. Otolaryngol Head Neck Surg 122: 834-841, 2000.

DVOŘÁNKOVÁ B, LACINA L, SMETANA K JR, LENSCH M, MANNING JC, ANDRÉ S, GABIUS H-J: Human galectin-2: nuclear presence in vitro and its modulation by quiescence/stress factors. Histol Histopathol 23: 167-178, 2008.

DUBOVÝ P, KLUSÁKOVÁ I, SVÍŽENSKÁ I: A quantitative immunohistochemical study of the endoneurium in the rat dorsal and ventral spinal roots. Histochem Cell Biol 117: 473-480, 2002.

GABIUS H-J: Cell surface glycans: the why and how of their functionality as biochemical signals in lectin-mediated information transfer. Crit Rev Immunol 26: 43-79, 2006.

GABIUS H-J (ed): The Sugar Code. Fundamentals of Glycosciences. Wiley-VCH, Weinheim, Germany, 2009.

GABIUS H-J, WOSGIEN B, HENDRYS M, BARDOSI A: Lectin localization in human nerve by biochemically defined lectin-binding glycoproteins, neoglycoprotein and lectin-specific antibody. Histochemistry 95: 269$277,1991$.

GABIUS H-J, SIEBERT H-C, ANDRÉ S, JIMÉNEZ-BARBERO J, RÜDIGER H: Chemical biology of the sugar code. ChemBioChem 5: 740-764, 2004.

HOLÍKOVÁ Z, HRDLIČKOVÁ-CELA E, PLZÁK J, SMETANA K JR, BETKA J, DVOŘÁNKOVÁ B, ESNER M, WASANO K, ANDRÉ S, KALTNER H, MOTLÍK J, HERCOGOVÁ J, KODET R, GABIUS H-J: Defining the glycophenotype of squamous epithelia by plant and mammalian lectins. Differentiation-dependent expression of $\alpha 2,6$ - and $\alpha 2,3$-linked $\mathrm{N}$-acetylneuraminic acid in squamous epithelia and carcinomas and its differential effect on binding of the endogenous lectins galectins-1 and -3. APMIS 110: 845-856, 2002.

KALTNER H, SEYREK K, HECK A, SINOWATZ F, GABIUS H-J: Galectin-1 and galectin-3 in fetal development of bovine respiratory and digestive tracts. Cell Tissue Res 307: 35-46, 2002.

KOPITZ J, VON REITZENSTEIN C, BURCHERT M, CANTZ M, GABIUS H-J: Galectin-1 is a major receptor for ganglioside GM1, a product of the growth-controlling activity of a cell surface ganglioside sialidase, on human neuroblastoma cells in culture. J Biol Chem 273: 11205-11211, 1998.

KOPITZ J, VON REIZENSTEIN C, ANDRÉ S, KALTNER H, UHL J, EHEMANN V, CANTZ M, GABIUS H-J: Negative regulation of neuroblastoma cell growth by carbohydrate-dependent surface binding of galectin-1 and functional divergence from galectin-3. J Biol Chem 276: 35917-35923, 2001.

KOPITZ J, ANDRÉ S, VON REIZENSTEIN C, VERSLUIS K, KALTNER H, PIETERS RJ, WASANO K, KUWABARA I., LIU F-T, CANTZ M, HECK AJR, GABIUS H-J: Homodimeric galectin-7 (p53-induced gene 1) is a negative regulator for human neuroblastoma cells. Oncogene 22: 6277-6288, 2003.

LANGBEIN S, BRADE J, BADAWI JK, HATZINGER M, KALTNER H, LENSCH M, SPECHT K, ANDRÉ S, BRINCK U, ALKEN P, GABIUS H-J: Gene-expression signature of adhesion/growth-regulatory tissue lectins (galectins) in transitional cell cancer and its prognostic relevance. Histopathology 51: 681-690, 2007.

LENSCH M, LOHR M, RUSSWURM R, VIDAL M, KALTNER H, ANDRÉ S, GABIUS H-J: Unique sequence and expression profiles of rat galectins-5 and -9 as a result of species-specific gene divergence. Int J Biochem Cell Biol 38: 1741-1758, 2006. 
LOHR M, LENSCH M, ANDRÉ S, KALTNER H, SIEBERT H-C, SMETANA K JR, SINOWATZ F, GABIUS H-J: Murine homodimeric adhesion/growth-regulatory galectins-1, -2, and 7: Comparative profiling of gene/promoter sequences by database mining, of expression by RT-PCR/immunohistochemistry and of contact sites for carbohydrate ligands by computational chemistry. Folia Biol (Praha) 53: 109-128, 2007.

LOHR M, KALTNER H, LENSCH M, ANDRE S, SINOWATZ F, GABIUS H-J: Cell-type-specific expression of murine multifunctional galectin-3 and its association with follicular atresia/luteolysis in contrast to proapoptotic galectins-1 and -7. Histochem Cell Biol 130: 567-581, 2008.

LÓPEZ-LUCENDO MF, SOLÍS D, ANDRÉ S, HIRABAYASHI J, KASAI K-I, KALTNER H, GABIUS H-J, ROMERO A: Growth-regulatory human galectin-1: crystallographic characterisation of the structural changes induced by single-site mutations and their impact on the thermodynamics of ligand binding. J Mol Biol 343: 957-970, 2004.

MADSEN P, RASMUSSEN HH, FLINT T, GROMOV P, KRUSE TA, HONORÉ B, VORUM H, CELIS JE: Cloning, expression, and chromosome mapping of human galectin-7. J Biol Chem 270: 5823-5829, 1995.

MAGNALDO T, BERNERD F, DARMON M: Galectin-7, a human 14-kDa S-lectin, specifically expressed in keratinocytes and sensitive to retinoic acid. Dev Biol 168: 259-271, 1995.

MATOUŠKOVÁ E, VESELÝ P, KÖNIGOVÁ R: Modified method of in vitro cultivation of human keratinocytes suitable for grafting. Folia Biol 35: 267-271, 1989.

MOTLÍK J, KLÍMA J, DVOŘÁNKOVÁ B, SMETANA K JR: Porcine epidermal stem cells as a biomedical model for wound healing and normal/malignant epithelial cell propagation. Theriogenology 67: 105-111, 2007.

PLZÁK J, SMETANA K JR, BETKA J, KODET R, KALTNER H, GABIUS H-J: Endogenous lectins (galectins-1 and -3) as probes to detect differentiation-dependent alterations in human squamous cell carcinomas of oropharynx and larynx. Int J Mol Med 5: 369-372, 2000.

PLZÁK J, SMETANA K JR, HRDLIČKOVÁ E, KODET R, HOLÍKOVÁ Z, LIU F-T, DVOŘÁNKOVÁ B, KALTNER H, BETKA J, GABIUS H-J: Expression of galectin-3-reactive ligands in squamous cancer and normal epithelial cells as a marker of differentiation. Int J Oncol 19: 59-64, 2001.

PLZÁK J, HOLÍKOVÁ Z, SMETANA K JR, DVOŘÁNKOVÁ B, HERCOGOVÁ J, KALTNER H, MOTLÍK J, GABIUS H-J: Differentiation-dependent glycosylation of cells in squamous epithelia detected by a mammalian lectin. Cells Tissues Organs 171: 135-144, 2002.

PLZÁK J, BETKA J, SMETANA K JR, CHOVANEC M, KALTNER H, ANDRÉ S, KODET R, GABIUS H-J: Galectin-3: an emerging prognostic indicator in advanced head and neck carcinoma. Eur J Cancer 40: 23242330, 2004.

POLYAK K, XIA Y, ZWEIER JL, KINZLER KW, VOGELSTEIN B: A model for p53-induced apoptosis. Nature 389: 300-305, 1997.

PURKRÁBKOVÁ T, SMETANA K JR, DVOŘÁNKOVÁ B, HOLÍKOVÁ Z, BÖCK C, LENSCH M, ANDRÉ S, PYTLÍK R, LIU F-T, KLÍMA J, SMETANA K, MOTLÍK J, GABIUS H-J: New aspects of galectin functionality in nuclei of cultured bone marrow stromal and epidermal cells: biotinylated galectins as tool to detect specific binding sites. Biol Cell 95: 535-545, 2003.

ROTBLAT B, NIV H, ANDRÉ S, KALTNER H, GABIUS H-J, KLOOG Y: Galectin-1 (L11A) predicted from a computed galectin-1 farnesyl-binding pocket selectively inhibits Ras-GTP. Cancer Res 64: 3112-3118, 2004.

SAUSSEZ S, DECAESTECKER C, MAHILLON V, CLUDTS S, CAPOUILLEZ A, CHEVALIER D, KALTNER H, ANDRÉ S, TOUBEAU G, LEROY X, GABIUS H-J: Galectin-3 upregulation during tumor progression in head and neck cancer. Laryngoscope 118: 1583-1590, 2008a.

SAUSSEZ S, LORFEVRE F, DECAESTECKER C, CHEVALIER D, KALTNER H, ANDRÉ S, TOUBEAU G, GABIUS H-J, LEROY X: Increased expression and altered intracellular distribution of adhesion/growthregulatory lectins galectins-1 and -7 during tumour progression in hypopharyngeal and laryngeal squamous cell carcinomas. Histopathology 52: 483-493, $2008 \mathrm{~b}$.

SIEBERT H-C, ANDRÉ S, LU SY, FRANK M, KALTNER H, VAN KUIK JA, KORCHAGINA EY, BOVIN NV, TAJKHORSHID E, KAPTEIN R, VLIEGENTHART JFG, VON DER LIETH C-W, JIMÉNEZ-BARBERO J, KOPITZ J, GABIUS H-J: Unique conformer selection of human growth-regulatory lectin galectin-1 for ganglioside GM1 versus bacterial toxins. Biochemistry 42: 14762-14773, 2003. 
SMETANA K JR, DVOŘÁNKOVÁ B, CHOVANEC M, BOUČEK J, KLÍMA J, MOTLÍK J, LENSCH M, KALTNER H, ANDRÉ S, GABIUS H-J: Nuclear presence of adhesion-/growth-regulatory galectins in normal/malignant cells of squamous epithelial origin. Histochem Cell Biol 125: 171-182, 2006.

UNVERZAGT C, ANDRÉ S, SEIFERT J, KOJIMA S, FINK C, SRIKRISHNA G, FREEZE H, KAYSER K, GABIUS H-J: Structure-activity profiles of complex biantennary glycans with core fucosylation and with/without additional $\alpha 2,3 / \alpha 2,6$ sialylation: synthesis of neoglycoproteins, and their properties in lectin assays, cell binding, and organ uptake. J Med Chem 45: 478-491, 2002.

VILLALOBO A, NOGALES-GONZÁLEZ A, GABIUS H-J: A guide to signaling pathways connecting protein-glycan interaction with the emerging versatile effector functionality of mammalian lectins. Trends Glycosci Glycotechnol 8: 1-37, 2006.

WU AM, WU JH, LIU J-H, SINGH T, ANDRÉ S, KALTNER H, GABIUS H-J: Effects of polyvalency of glycotopes and natural modifications of human blood group $\mathrm{ABH} /$ Lewis sugars at the Gal $\beta 1$-terminated core saccharides on the binding of domain-I of recombinant tandem-repeat-type galectin-4 from rat gastrointestinal tract (G4-N). Biochimie 86: 317-326, 2004.

WU AM, SINGH T, WU JH, LENSCH M, ANDRÉ S, GABIUS H-J: Interaction profile of galectin-5 with free saccharides and mammalian glycoproteins: probing its fine specificity and the effect of naturally clustered ligand presentation. Glycobiology 16: 524-537, 2006. 